УДК 821.161.2-31.09 Дочинець

Мельник Наталя, кандидат філологічних наук, доцент, завідувач кафедри української

та світової літератур Криворізький державний педагогічний університет

\title{
РОМАН М. ДОЧИНЦЯ «ВІЧНИК. СПОВІДЬ НА ПЕРЕВАЛІ ДУХУ» ЯК ФОЛЬКЛОРНИЙ МЕТАТЕКСТ
}

У статті досліджуютъся функиї фольклорного метатексту в романі М. Дочини,я «Вічник. Сповідъ на перевалі духу».

Спираючисъ на сучасні концепцї метатексту, розуміючи фольклор як комплекс народних знань, утілених у художнному тексті в різних бормах, авторка визначае зв'язок змісту досліджуваного роману $з$ болъклорною свідомістю, окреслюе функиї̈ болъклорного метатексту.

Використання писъменником великого формалъного та змістового арсеналу украӥнсъкого болъклору сприяе формуванню иілісної ідейнохудожнъої концепцї твору, визначае його смислове навантаження, моделюе наративні стратегіӥ тексту. У роман залучено широкий жсанровий діапазон болъклорної системи (молитви-замовляння, легенди, перекази, прислів'я та приказки, лікувалъні замовляння); концепти світоглядних уявленъ, традиційні фольклорні прийоми творення образів, що дозволяе носієві культурной націоналъної традиції сприймати твір на архетипно-асочіативному рівні. Фольклорна першооснова твору виконуе текстоутворюючу бункцію, окреслюе його комунікативну настанову та сприяе вірогідності описуваного. Такий підхід призводитъ до співтворчості читача, визначае колективність авторсъкого наративу.

Ключові слова: метатекст, фолъклор, роман, художні функиії.

Melnyk N. The novel "Vichnyk. Confession on the passage of the spirit" by Myroslav Dochynets as a folklore meta-text.

The article examines the folklore metatext functions in the novel "Vichnyk. Confession on the passage of the spirit" by M. Dochynets.

Drawing on modern concepts of metatext, understanding of folklore as a complex of folk knowledge, which embodied in artistic text by various forms, the author determines the connection of the content of the explored novel with folklore consciousness and outlines the folklore metatext functions.

The use of a large formal and content arsenal of Ukrainian folklore by writer contributes to the formation of a holistic ideological and artistic concept of the work, defines its semantic load, simulates the narrative strategy of the text. The novel involves a wide genre of folklore system (prayers-orders, legends, parables, proverbs and sayings, medical orders); the concepts of the worldviews, the traditional folklore techniques of the images creation, which 
allows the holder of cultural national tradition to perceive the work at the archetypal-associative level. Folklore primary basis of the work performs a text-forming function, outlines its communicative setting and contributes to the reliability of the described. This approach leads to the reader's co-creation and determines the collectivity of the author's narrative.

Key words: metatext, folklore, novel, artistic functions.

Постановка проблеми у загальному вигляді та ï зв'язок із важливими науковими чи практичними завданнями. Mетатекст як предмет наукового інтересу $\epsilon$ надзвичайно актуальним для сучасного літературознавства, фольклористики, герменевтики, теорії перекладу, лінгвістики. Визначення статусу, функцій метатексту в художньому тексті - одна з магістральних проблем новітньої філології.

Основи дослідження цієї проблеми закладені працями О. Потебні, Р. Якобсона, М. Бахтіна, Ю. Лотмана, які розглядали метатекст як певну «конструкцію, створену кимось для передання іншому чи іншим уявлень про якусь предметну галузь» [8].

Базовою для розуміння сутності поняття метатекст традиційно вважається праця А.Вежбицької «Метатекст у тексті» (1978), в якій окреслено функції метатекстових «ниток», які оприявлюють «семантичний» візерунок основного тексту», поєднують, підсилюють, зміцнюють різні його елементи [3].

Аналіз останніх досліджень і публікацій 3 даної теми. Спираючись на сучасні літературознавчі концепції, у праці «Проблема визначення метатексту в художньому тексті» (2009), Н.Лукіна трактує метатекст як інформаційно-культурну сферу, яка оточує письменника та реалізується ним через композицію, художні прийоми. Ця сфера впливає на сприйняття тексту загалом та окремих його частин i як певна сукупність текстів, створених одним письменником, і як сукупність текстів, що відносяться до одного літературного напряму [5]. На думку науковця, це «сукупність метазасобів, які позначають присутність того, хто говорить / пише в тексті (до них ми відносимо метамаркери, метатекстові компоненти, метатекстові висловлювання та метатекстові фрагменти) та організуючих собою рівень тексту, який несе певне функціональне та смислове навантаження, визначене авторським задумом» [5].

У дослідженні «Проблема метатексту в сучасній лінгвістиці» (2010) О.Буров указує на складність та багаторівневість проблеми дослідження метатексту, який розуміється науковцями по-різному: як «сукупність метатекстових елементів, що виконують переважно структуруючу та комунікативну функції в тексті»; як «явище 
200Літератури світу: поетика, ментальність і духовністъ. 2020. Bип.14

соціального, психологічного, комунікативного та риторичного характеру, що виконує різні функції; як «текст про текст» тощо. Науковець дотримується позиції, що метатекст - це «прагматичне, функціонально-семантичне явище, притаманне будь-якому писемному чи усному тексту, наділене текстоутворюючою потенцією (будівельна, організуюча функція) [2].

У праці «Метатекст у рецепивному контексті» (2010) О. Бердник трактує поняття метатекст як органічну складову теоретиколітературознавчого аналізу, що означає «змінений, перетворений текст» [1].

О. Черновол-Ткаченко, О. Пєшкова у статті «Особливості визначення статусу метатекста в науковому дискурсі» (2014) виокремлюють такі типи метатексту: інтрометатекст (метатекстові оператори, вплетені в тканину основного тексту: частини висловлювання, в яких виражені мовленнєві смисли, вставні слова, речення, вставні конструкції, предикативні частини складних речень, окремі абзаци) та сепаративний метатекст (композиційно дистанційовані від основного тексту утворення: вступ. передмова, коментарій, примітки в формі зносок, абзаци) [8].

У праці О. Івановської «Фольклор як суб'єктно-образна система» (2009) фольклор трактується як «комплекс народних знань, як система ідей, втілених у різноманітних вербальних і невербальних формах»; «образна система традиційних смислів» [6]. Ми погоджуємося з таким розумінням фольклорного феномену, як із думкою про зближення усної та письмової традицій, притаманне сучасній добі, та тезою про «експлікацію фольклорного надбання у $<\ldots>$ «нефольклорні» тексти культури і буденності» [6].

У руслі нашого дослідження такий підхід до осмислення феноменів фольклорного та літературного текстів логічно визначає напрямок даної наукової студії.

Мета статті - визначення функцій фольклорного метатексту в романі М. Дочинця «Вічник. Сповідь на перевалі духу».

Виклад основного матеріалу дослідження. Твори сучасного українського письменника М. Дочинця невипадково сьогодні набули особливої популярності, адже пропонують читачеві позитивну, традиційну модель життя людини в гармонії з природою, в тісному зв'язку зі перевіреними часом і простором, світоглядними уявленнями наших пращурів. На думку О. Щур, «Українсъкий Коельйо: Мирослав Дочинець зумів угадати запити типового читача» [9]. 
Т. Фасоля вважає, що книги письменника, зокрема цикл творів про Андрія Ворона, «...можсна вважати найуспішнішою літературною містифікачією останніх років. На жаль, не найякіснішою. Містифікований $і$ Андрій Ворон. I його життя, і весъ народ» [7].

Ми не погоджуємося з такою оцінкою творчого доробку письменника. На нашу думку, роман М. Дочинця «Вічник. Сповідь на перевалі духу» являє собою багатогранний цілісний фольклорний метатекст, що логічно, глибино, свідомо і підсвідомо пов'язаний із фольклорною традицією українського народу. Власне, фольклор як складна i багатогранна система, є тим структуроутворюючим, формувальним, організуючим чинником твору, що визначає його ідейно-художні координати.

Головний персонаж роману - Вічник-Андрій Ворон ділиться з читачем історією власного життя, що уособлює життєвий шлях особистості, яка, в умовах тоталітарного суспільства намагається зберегти особисту і національну гідність, отримати духовну свободу: «Упосліджений світом і покинутий людъми, замкнений у кам'яній коморі Природи, - знайшов я свободу волі $i$ радість ширяння $\partial y x y \gg[4$, c. 5$]$.

Із погляду мудрої, досвідченої, духовної людини, генетично пов'язаної з родом, нацією, традиційними світоглядними уявленнями свого народу, в творі висловлено позачасові, «вічні» життєві істини: «<..> маю що видобути зі споду душі $i$ мушу; $i$ прошу на се благословення, сил і снаги, щоб написане мною не мертвим саваном лягло в гробівець пам'яти, - а живою водою на людсъкий хосен $i$ спожиток $\langle\ldots>$ Hате $\langle\ldots>$ скарб моєї душі $i$ miла» $[4$, с. 4].

Усвідомлену відповідальність митця перед своїм народом та мету власної творчості автор укладає в уста головного персонажа роману: «Писъмовещь - як волхв, що виправдовуе перед лищем господа перебування свого народу на землі <..> I смисл усякого писъма $в$ тому, щоб укріпити в людності дух доброчесності - найбільше $з$ благ. Щоб покликати людину на проблиск світла в чорноті. Бо той, хто творить, шукає підпору в Твория. I писати слід простими, ваговитими й дзвінкими словами» [4, с. 154].

У основі ідейно-художньої концепції роману - глибоке фольклорне підгрунтя, яке моделює текст у межах традиційної народної свідомості.

Про природне поєднання язичницьких та християнських основ народного світогляду свідчить наявність у творі молитов-замовлянь, що традиційно супроводжували релігійні обряди. 
202 Літератури світу: поетика, ментальність і духовністъ. 2020. Bип.14

У романі зустрічаємо молитви-замовляння на Святий вечір, Водохреща: «на Святий вечір дідо брав в одну руку суху отаву, в другу - яворове Ілієве кося $і$ обходив тричі хижу, приказуючи: "Всевишній Господи, що сотворив Світ, Сонце, Місяць, Зорі на небесах. Як чоловік не годен їм нич лихого зробити, дай так, аби й мені нич не могли зробити, поможи моїи сім'й, дай сили, сохрани маржини, щоб давали доста молока і весь наш рід був ситий” [4, с. 33]; «На Водохреша, після освячення води в криниці, дідо вмочував у ней кося верхнім і нижнім кінцем $і$ примовляв: "Як помагае ся свята вода людям, так аби мое кося помагало мені у всякій біді $i$ всю нечисть від мене відганяло, i тіло й душу мою спасало” [4, с. 33].

Звільнення від вражень поганих снів, заспокійливі замовляння, що Грунтуються на тотемічних уявленнях українського народу: «Дубе, дубе чорний. У тебе дубочки-синочки і дубочки-дочки. Тобі, дубе, шуміти й густи, а мені, безрідно рожденному, хрещеному спати й рости. Понеділок з вівторком, середа з четвергом, п'ятнии,я з суботою, неділенька-удовии,я, - най добрий сон мені присниться!» [4, с. 49].

У цих зверненнях до Вищих сил - розуміння єдності та взаємопов'язаності всього живого на землі, де людина - рівноправна частина природи, рівноцінна дереву, тварині, птахові, проте, не вища за них. Тому й звертатися до них слід лише з повагою та усвідомленням кровного зв'язку між усім сущим. Добуваючи березовий і кленовий соки, мудра людина має промовити: «Я теж дерево лише, ходяче, що потребуе земних соків. I мої соки теж колись стечуть-повернуться в землю $і$ мене запечатають у жбан вічності» [4, с. 66].

Аптекар Джеордже, який дає притулок Андрієві, а потім учить його готувати ліки, вважає живою і рівною людині навіть траву: «Ce був волхв трави, він молився на неї, він знав з нею розмовляти. "Трава - як чоловік <..> Корінням держиться земля, а душею тягнеться до неба. Бо звідти вона посіяна трава має розум, мае слух i пам'ять"» [4, с. 134-135].

Знаковими в творі є історії про зустрічі людини з вороном, ведмедем, жабою, змією, риссю, тигром, розмови з ними та досягнення згоди. Так, Вічник, у час своїх поневірянь, зцілюється після виконання певних магічних ритуалів та домовленості зі змією-царицею; рятуючись, звертається до птаха: «Брате вороне, я ще не твій, - сказав я йому $i$ сам здивувався доброті свого голосу, - Хіба ти забув, що ворон ворону око не видовбе?» [4, с. 38]. Китаєць Чао Бао домовляється з тигром: «Чао Бао перемовлявся з ним гучним поважним голосом, запевняв, що не хоче переступити йому дорогу. I тигр ішов собі» [4, с. 236]. 
Визначальною формулою для такого спілкування є усвідомлення тимчасовості та конечності людського життя, яке підлягає вічним законам природи. Вбиваючи звіра задля власного виживання в лісі, головний персонаж роману знаходить пояснення і виправдання своїм діям у розумінні їх закономірності, адже колись і він стане певною корисною для когось субстанцією: «Тою ж силою, що повалила тебе, сильний звіре, я теж колись буду стятий $i$ відданий комусь на поживу. Той же закон, що віддав тебе в мої руки, колись віддасть $i$ мене в ще могутніші руки. Бо й ти $і$ я - ми лише питомий порох вічного коловороту життя» [4, с. 91].

У основі такого світогляду - шанобливе ставлення до землі, вогню, води. Головний персонаж роману вчиться цьому протягом усього життя. Всі, хто, зустрічаються йому на шляху (дід, баба, мати, вуйко Ферко, професор Матіко, румун Джеордже, святі отці, дід Петро Стойка, крітянин Захаріос, китаєць Чан Бао), є вчителями мудрості. Уважному і чутливому до всього, чому його може навчити життя, вдячному кожному, хто поділився з ним корисними знаннями, Андрієві врешті вдається виробити цілісну концепцію людини та дійсності, що є суголосною вічним законам Усесвіту.

Про діда, котрий першим відкрив хлопчикові таємниці життя людини в гармонії з природою, в творі говориться: «дідо $\langle\ldots>$ білъше ходив босим, «нерідко і взимі перебігав так двором. Куди б не їздв, на возі мав корчажку свіжої води, яку за день випивав. «Вода чистить мозок, як скло, - любив приповідати. - Радо ї̈ пий $і$ споживай те, що зросло на воді й на сонці, і будеш чистим і твердим, як скло» [4, с. 15].

Пройшовши складний життєвий шлях, набувши цінного досвіду, Андрій Ворон приходить до висновку: «Bсі ми вийшли з води. 3 води живемо, водою христимося. Водна очищае наші душі й омивае кости, а відтак піднімаеться в небо паро, щоб упасти дощем, щоб спородити й напоїти инших. Кожний з нас - то жива крапелина води, що $\epsilon$ земною і небесною водночас $<\ldots>$ Навчіться любити воду. Всъому іншому вона вас навчитъ» [4, с. 13].

Із китайцем Чан Бао Вічник пізнає основи східної мудрості: «Ніколи нікуди не поспішай. I завжди встигнеш... Не хапайся гарячково за роботу - $i$ все зробиш вчасно. А якщо й не зробиш, то й не біда, зробить хтось інший <..> Слухай, що говорить вода; дивися, що показуе вогонь; черпай розум лісу. Вони старші за тебе $і$ навчать, як чинити... Якщо хочеш щось дістати, перше дай те, що хочеш дістати. Завжди давай першим. Якщо не маєш що дати, дай усмішку чи молитву. Все годиться для давання...» [4, с. 235]. 
204Літератури світу: поетика, ментальність $i$ духовність. 2020. Bип. 14

Прислів'я та приказки, використані в творі, не лише ілюструють закоріненість у національну традицію персонажів твору, але й свідчать про здоровий Глузд простої людини, її практичний погляд на життя та веселу вдачу: «Не будеш пити - нич не втратиш. Будеш много пити втратиш усе» [4, с. 16]; «Глядай не на долю, а на волю» [4, с. 16]; «Коби здоров'я, а гріхи будутъ» [4, с. 18]; «Многі ворони $i$ коня вбалятъ» [4, c. 18] «Розумний пес на вітер не гавкає» $[4$, с. 18]; «Чесному честь $i$ під лавицею» [4, с. 18]; «Кедъ робиш махом - піде прахом» [4, с. 18]; «Чоловік пахне вітром, а жона - димом» [4, с. 18, 54]; «Голого ремінь грiє» [4, с. 18]; «Біда вимучить, біда й виучить» [4, с. 18]; «Який корч, такий $i$ прутик» [4, с. 18]; «Від рівного дерева рівна й тінъ» [4, с. 18]; «Хто терпен, той спасен» [4, с. 31]; «Така моя доля - як дірява льоля» $[4$, с. 71]; «Нехотя-нехотя з'ӥ $і$ крихотя» [4, с. 159]; «Ліпше з розумним загубити, чей з дурним найти» [4, с. 162].

У романі досить значним є шар фольклорної демонологіі: легенди та перекази про повітруль, босоркань, чар-тріску, яку отримав діді, косичку папороті, що є природною складовою вірувань закарпатців. Життя в певною мірою локальних, обмежених горами, умовах, спричинило до особливої життєвості таких творів, їх природного поєднання з християнськими канонами.

У романі сформульовано певну модель ідеального природного життя людини. Автор пропонує читачеві цілісний образ людини з народу, яка, попри політичні, історичні перипетї залишається цілісною особистістю, орієнтуючись на вічні закони буття. Поради щодо такого способу існування, поза викликами часу і простору, сформульовані Петром Стойкою: «иілість тіла, духу й серия. Жити треба твердо і радо. Не ламати себе $i$ не повоювати. Ні в роботі, ні в жаданні, ні в помислі. Бо чоловік не гадина - і розсічені кусні тіла й душі не відживуть. Проси собі иілості. Будъ у єдності з собою. Будъ одним, а не різним. Будъ одному вірний. Будъ з одним до кіния, а не з різними коротко. Будъ з одною жоною, бо в ній $\epsilon$ все, що $і$ в инших, $і$ лише - для тебе. I в ватрі - дрова $i$ чоловічого, $і$ жіночого роду. Тоді вона добре горить. Якщо маєш у собі иілість, то ти як зернина, що впала на землю. Вона вітру не глядає» [4, с. 159].

Спостерігаючи за життям русинів у румунському краї, оповідач узагальнює і репрезентує основні традиційні заповіді гармонійного природного цілісного життя людини: вставати з сонцем, лягати 3 зорями; день починати і завершувати молитвами; з пошаною ставитися до старших у родині, бути відкритими, добросердними, творчими [4, c. 159-160]. 
У романі творчо використано коломийки-співанки філософського [4, c. 160] та любовного [4, с. 68, 69, 164] змісту, які природно доповнюють, уяскравлюють образи твору й логічно пов'язані з його сюжетом. Вони репрезентують результати філософського осмислення народом ідеї плинності людського життя, висловлюючи ї̈ в традиційних фольклорних моделях:

Коли собі заспіваю, а дале заплачу,

Літа мої молоденъкі, як вас дармо трачу.

Літа мої молоденъкі, молоді, молоді,

Та так мені марно йдете, як листок по воді...

Закувала зозулиия на дубовім мості,

Літа мої молоденъкі, ходіть до ня в гості [4, с. 160].

Висновки. Отже, спираючись на сучасні концепції метатексту, розуміючи фольклор як комплекс народних знань, утілених у художньому тексті в різних формах, ми спостерегли тісний зв'язок змісту досліджуваного роману з фольклорною свідомістю та визначили провідні функції фольклорного метатексту.

Використання письменником великого формально-змістового арсеналу українського фольклору, на нашу думку, сприяє формуванню цілісної ідейно-художньої концепції твору, визначає його смислове навантаження, моделює наративні стратегії тексту. У роман залучено широкий жанровий діапазон фольклорної системи (молитви-замовляння, легенди, перекази, прислів'я та приказки, коломийки-співанки, лікувальні замовляння); концепти світоглядних уявлень, традиційні фольклорні прийоми творення образів, що дозволяє носієві культурної національної традиції сприймати твір на архетипно-асоціативному рівні. Фольклорна першооснова твору виконує текстоутворюючу функцію, окреслює його комунікативну настанову та сприяе вірогідності описуваного. Такий художній підхід призводить до співтворчості автора з читачем, визначає колективність авторського наративу.

Перспективи подальших досліджень, на нашу думку, полягають у вивченні функцій фольклорного метатексту в художніх творах, що сприятиме глибинному розумінню складових їх поетики та зв'язку з національною культурною традицією загалом.

\section{Література}

1. Бердник O. Метатекст у рецепивному контексті. URL: http://irbisnbuv.gov.ua/cgi-bin/irbis_nbuv/cgiirbis_64.exe?C21COM=2\&I21D 
206Літератури світу: поетика, ментальність і духовністъ. 2020. Bип. 14

$\mathrm{BN}=\mathrm{UJRN} \& \mathrm{P} 21 \mathrm{DBN}=\mathrm{UJRN} \& I M A G E \quad$ FILE $\quad$ DOWNLOAD $=1 \&$ Image_file_name $=\mathrm{PDF} /$ apulf_2010_15_7.pdf

2. Буров A. А. Проблема метатекста в современной лингвистике. URL: https://pglu.ru/upload/iblock/f61/uch_2010_viii_00003.pdf

3. Вежбицкая А. Метатекст в тексте. Новое в зарубежной лингвистике. Вып.8. Лингвистика текста. Москва, 1978. С. 402-421. URL: http://destructioen.narod.ru/vegbicka_metatekst.htm

4. Дочинець М. I. Вічник. Мукачево: Карпатська вежа, 2017. 280 с.

5. Лукина Н. В. Проблема выделения метатекста в художественном тексте. Вестник РУДН, Серия: Русский и иностранные языки и методика их преподавания. 2009. № 3. URL: https://cyberleninka.ru /article/n/problema-vydeleniya-metateksta-v-hudozhestvennomtekste

6. Івановська О. Фольклор як суб'єктно-образна система. Міфологія і фольклор. 2009. №1(2). URL: http://publications. lnu.edu.ua/journals/index.php/mythology/article/view/871

7. Фасоля Т. Вороняча мудрість від Мирослава Дочинця. ЛітАкцент. 2013. 20 лютого URL: http://litakcent.com/2013/02/20/voronjachamudrist-vid-myroslava-dochyncja/

8. Черновол-Ткаченко О.А., Пешкова О.Г. Особенности определения статуса метатекста в научном дискурсе. Науковий вісник Міжнародного гуманітарного університету. Серія: Філологія. 2014. № 8. Том 1. URL: http://www.vestnikphilology.mgu.od.ua/archive/v8/v8-1/Filologi8-1.pdf $\#$ page $=220$

9. Щур О. Український Коельйо: Мирослав Дочинець зумів угадати запити типового читача. Тиждень. 2012. URL: https://tyzhden.ua/Culture/43807 